on November 19, 1883, at the early age of forty-five years was aneurysm of the aorta, the existence of which in his own person he had discovered about eighteen months previously while demonstrating the use of the binaural stethoscope. He nevertheless preferred to die in harness, a decision which met with the approval of Osler, among others.

\section{A New Treatment of Pneumonia}

SxNтHEтrc compounds possessing specific curative effects in various infections - chemotherapeutic agents' as they are termed-have long been sought for, though without much success, at least in bacterial infections. Three years ago, 'Prontosil', a sulphonamide compound, proved valuable in the treatment of streptococcal infections, such as puerperal fever. Quite recently, L. E. H. Whitby, investigating experimentally a number of synthetic compounds, found that one of them, 'M. \& B. 693', had a marked specific effect upon the pneumococcus, the microbe of human pneumonia, almost complete protection being afforded against Types $\mathrm{i}$, vii and viii pneumococcus infections, and a high degree of protection against Types ii, iii and $\mathrm{v}$ (Lancet, 1, No. 22, 1210 ; May 28, 1938). Encouraging clinical results in cases of pneumonia in man were reported by Evans and Gaisford (Lancet, 1, No. 23, 1305 ; June 4, 1938), and Telling and Oliver now give details of another case treated with this agent (Lancet, 1, No. 25, 1391 ; June 18, 1938). The patient, an old lady, was critically ill with pneumonia, pneumococcus Type iii being recovered from the sputum. After four days' treatment with the drug, recovery commenced and was finally complete. The observation was made that, in the course of treatment, the capsule which surrounds the pneumococcus became lost, and other changes in the organism were apparent. 'M. \& B. 693', chemically, is 2 -( $p$-aminobenzenesulphonamido) pyridine.

\section{Organization of Archæological Research in India}

As was pointed out recently in these columns (see Nature, May 28, p. 965) little advantage has been taken of the facilities for archæological exploration offered some years ago by the Government of India to bodies from outside the country, nor, if Dr. E. Mackay's excavations be excepted, has a serious and systematic attempt been made on any adequate scale to follow up the discovery of the now famous early civilization of the Indus Valley. An indication that a forward policy is now contemplated is afforded by an announcement of the India Office that Sir Leonard Woolley has accepted the invitation of the Government of India to visit the country next winter before proceeding to Syria to resume his excavations in the spring of 1939. The object of the invitation is to secure his advice in regard to a programme of archæological work. Among the matters upon which it is understood that Sir Leonard will be consulted are, first, the areas which are to be regarded as most promising for future excavation; secondly, the best methods and agencies to achieve the speedy and fruitful development of exploration activities, not only under Government auspices but also by non- official bodies, such as universities and learned societies; and last, the best method of training, or selecting, officers for exploration work, including such points as the most suitable age for recruitment. Since the control of the Archæological Survey has passed into Indian hands, much excellent work has. been done, more especially in those departments dealing with the growth of Indian civilization at. periods with which her countrymen perhaps are more familiar and more competent to speak than 'foreigners'. The archæology of India is a subject. for which her native students have shown both enthusiasm and aptitude; but they have had little opportunity to acquire the breadth of outlook which the study of the pre- and protohistory of their own country demands. The determination to seek out. side advice and the choice of an adviser are wise steps, from which archæological studies throughout the world may expect to reap considerable benefit.

\section{Peoples of Ancient Syria}

Ever since the recognition of Sumerian influence in the Indus valley through discoveries in the excavation of Mohenjodaro and Harappa, archæological investigation has added continuously to the evidence of the remarkable, and it may be said, unexpected degree and geographical extent of the contacts and movements of cultures and peoples even in the early stages of the development of civilized society. Now Mr. Sidney Smith, in a com. munication to The Times of June 16, indicates how a preliminary examination of the tablets from the Palace excavated by Sir Leonard Woolley at Atchana affords evidence of the extremely mixed character of the population of Syria in the fifteenth century B.C. In ancient times, it would appear, the site of Atchana was known as Alalakh. It was the capital of the country, Mukish-khe, mentioned in Hittite and Egyptian records. It was a vassal State of the kingdom of Mitanni, as appears from a tablet recording an attempt to establish citizenship of a Mitannian province, brought before the king of that people about 1450 B.c. by a subject of Niqmepa, ruler of Mukish-khe. The documents which have been found at Atchana, Mr. Smith states, concern the status of certain citizens, and are in the Akkadian language. From the names recorded it is possible to deduce that the population contained a considerable proportion of Babylonians and of Khurrians, an indigenous people in Mitanni, but spread over a considerable area extending from Kirkuk, east of the Tigris, to northern Palestine, and of whose existence no knowledge survived prior to modern excavation. Niqmepa may be a Khurrian name, but his son's name is Babylonian. This, Mr. Smith points out, is merely another phenomenon of a mixed civilization, in which the predominant elements were Babylonian, apart from local law and administration. He goes on to say that the inscribed seal, to which Sir Leonard Woolley referred in his report, is no proof of Hittite conquest. The language of the Hittite hieroglyphs is not Hittite, though it may be Indo-European. The seal is, therefore, merely further proof of the mixed character of the population. 